\title{
9 The development of the Chinese film production industry in 2018
}

\author{
Mingsong $\mathrm{Li}$
}

\section{Total number of films produced in China in $\mathbf{2 0 1 8}$}

The year 2018 is the 40th anniversary of China's Reform and Open Door policy. It is also the first year when the Publicity Department of the Communist Party of China (CPC) enforced a unified management policy on the Chinese film industry. The Film Industry Promotion Law was further implemented, and the reform of the film industry continued.

According to the data provided by the National Film Board, the total output of the films reached a new record. Some 1,082 films in total were produced in 2018, which includes 902 feature films, 51 animation films, 61 science fiction and education films, 57 documentary films, and 11 films of special categories. Both the number of feature films and the total number of films being produced increased by 13 percent and 11.55 percent, respectively, compared with that of 2017 (Table 9.1).

From 2014 to 2018, the government's support for film policies and the popularity of the film market increased the number of Chinese films produced, year on year, and the government's strong supervision and the benign competition in the industry have brought about improvement in the quality of domestic film production. In 2018, high-quality films emerged, and many films with ideological, artistic and entertaining content were successful at the box office through word-of-mouth reputation. There were 82 films that broke the box office record of 100 million yuan, and 16 of them broke the box office record of 1 billion yuan. Among them, there are many excellent works that gained both public praise and good box office, such as Operation Red Sea, in which the scenery is magnificent, Dying to Survive, which reflects reality and contains great humor, Running to the Spring and The Photographer, which pay tribute to the 40th anniversary of the Reform and Open Door policy and triggered a warm response from the public.

\section{Analysis of domestic film production in 2018}

In April 2018, Huang Kunming, a member of the Political Bureau of the CPC Central Committee, the Secretary of the Secretariat of the CPC Central 
Table 9.1 National film production, 2000-2018

\begin{tabular}{lllllll}
\hline Year & $\begin{array}{l}\text { Feature } \\
\text { films }\end{array}$ & $\begin{array}{l}\text { Animation } \\
\text { films }\end{array}$ & $\begin{array}{l}\text { Science fiction } \\
\text { and education } \\
\text { films }\end{array}$ & $\begin{array}{l}\text { Documentary } \\
\text { films }\end{array}$ & $\begin{array}{l}\text { Special } \\
\text { films }\end{array}$ & $\begin{array}{l}\text { Total } \\
\text { number } \\
\text { of films }\end{array}$ \\
\hline 2000 & 91 & 1 & 49 & 10 & 0 & 151 \\
2001 & 88 & 1 & 56 & 9 & 0 & 154 \\
2002 & 100 & 2 & 60 & 7 & 0 & 169 \\
2003 & 140 & 2 & 53 & 6 & 0 & 201 \\
2004 & 212 & 4 & 30 & 10 & 0 & 256 \\
2005 & 260 & 7 & 33 & 2 & 0 & 302 \\
2006 & 330 & 13 & 36 & 13 & 0 & 392 \\
2007 & 402 & 6 & 34 & 9 & 0 & 451 \\
2008 & 406 & 16 & 39 & 16 & 2 & 479 \\
2009 & 456 & 27 & 52 & 19 & 4 & 558 \\
2010 & 526 & 16 & 54 & 16 & 9 & 621 \\
2011 & 558 & 24 & 76 & 26 & 5 & 689 \\
2012 & 745 & 33 & 74 & 15 & 26 & 893 \\
2013 & 638 & 29 & 121 & 18 & 18 & 824 \\
2014 & 618 & 40 & 52 & 25 & 23 & 758 \\
2015 & 686 & 51 & 96 & 38 & 17 & 888 \\
2016 & 772 & 49 & 67 & 32 & 24 & 944 \\
2017 & 798 & 32 & 68 & 44 & 28 & 970 \\
2018 & 902 & 51 & 61 & 57 & 11 & 1082 \\
\hline
\end{tabular}

Source: China Statistical Yearbook, various years.

Committee, and the Minister of the Publicity Department of the Communist Party of China, delivered a speech at a film production and research symposium, emphasizing the need to thoroughly study and implement Xi Jinping's ideologies of the new era of Chinese socialism to build China into a country with a prosperous film industry. Taking the opportunity to celebrate the 40th anniversary of the Reform and Open Door policy, and celebrate also the 97th anniversary of the founding of the Communist Party of China, a number of mainstream films, such as The Photographer, Running to the Spring, Hope of Road, Li Baoguo, The Connection and The Faithful, were released.

The films released in China in 2018 continued to show great diversity in terms of themes, genres and production patterns. They achieved remarkable social and economic success. It is worth mentioning that realism in films gained great public praise and good box office in 2018, in films such as Dying to Survive, which ranked third place at the annual box office, and the romantic film $U s$ and Them, the comedy Hello Mr. Billionaire (Mahua Fun Age), Take My Brother Away, Cry Me a Sad River, and Einstein and Einstein, and so on. Although these films are all of different genres, they all present appropriate and realistic portrayals of relevant real life and events. Realist films have become an important carrier for national identity. The stories of these films evoked strong emotional responses from the audiences. 
Table 9.2 Top 30 domestic box office tickets in 2018 (¥ ten thousand)

\begin{tabular}{|c|c|c|c|}
\hline Rank & Movie title & Main genre & Box office \\
\hline 1 & Operation Red Sea & Action & 365077.8 \\
\hline 2 & Detective Chinatown 2 & Comedy & 339768.8 \\
\hline 3 & Dying to Survive & Feature & 309996.1 \\
\hline 4 & Hello Mr. Billionaire & Comedy & 254757.2 \\
\hline 5 & Monster Hunt 2 & Comedy & 223707.7 \\
\hline 6 & Us and Them & Romantic & 136151.5 \\
\hline 7 & The Island & Comedy & 135504.8 \\
\hline 8 & Project Gutenberg & Action & 127376.3 \\
\hline 9 & The Meg & Action & 105178.1 \\
\hline 10 & How Long Will I Love You? & Fantasy & 89988.4 \\
\hline 11 & A Cool Fish & Feature & 79408.6 \\
\hline 12 & Forever Young & Feature & 75429.7 \\
\hline 13 & The Monkey King 3 & Comedy & 72738.2 \\
\hline 14 & Shadow & Action & 62898.9 \\
\hline 15 & Detective Dee & Action & 60634.3 \\
\hline 16 & Bear Emergence & Animation & 60550.3 \\
\hline 17 & Hello, Mrs. Money & Comedy & 60435.2 \\
\hline 18 & Hidden Man & Action & 58348.3 \\
\hline 19 & Ipartment & Comedy & 55472.7 \\
\hline 20 & Animal World & Action & 50967.7 \\
\hline 21 & Amazing China & Documentary & 48056.3 \\
\hline 22 & L Storm & Feature & 44298.4 \\
\hline 23 & Take My Brother Away & Comedy & 37531.4 \\
\hline 24 & $A$ or $B$ & Feature & 35861.1 \\
\hline 25 & Cry Me a Sad River & Feature & 35664.9 \\
\hline 26 & Golden Job & Action & 31527.5 \\
\hline 27 & Lost, Found & Feature & 28528.3 \\
\hline 28 & Fat Buddies & Comedy & 26106.6 \\
\hline 29 & Till the End of the World & Romantic & 23448.3 \\
\hline 30 & Meng vers la Rivière & Comedy & 20364.6 \\
\hline
\end{tabular}

Source: Entgroup Data.

Thus, the public welcomed the return of cinema realism and this eventually resulted in the excellent performance of these movies at the box office. By presenting the real-life conditions of Chinese people, these realistic films are truly praised and appreciated by the Chinese public. Thus, themes of social care and emotional love stories have become common themes for film producers in China.

According to Table 9.2, based on the distribution of the top 30 domestic box office outlets in 2018, comedy and action genres have become the most mainstream commercial film genres. There are many films of a hybrid genre that mix comedy elements in the top 5 domestic films at the box office. In recent years, the genres of film production have become more sophisticated, and the themes of the films have become more popular. Films mixing two 
or more genres have become popular. There are many movies like this in the top 30 of the box office in 2018, such as Detective Chinatown 2. Although the main storyline of this film is a typical suspense crime story, it also had many comedy generic codes and conventions in terms of characterization and narrative structure. The mixture of a detective story with comedy elements presents an alternative viewing experience and led to its box office success. Project Gutenberg is similar to Detective Chinatown 2. The film is both crime and action genre, and it successfully presented a fascinating suspense atmosphere with the film's twist of plots to its audiences. The "split personality" in this film also brings the story to climax that subverts audiences' conventional understanding of the story. The mixture of action, crime and suspense elements makes this film highly appealing to the public. Another low-budget movie How Long Will I Love You? is mainly a romantic film with time travel plots in the story. The magical elements and the theme of love are ingeniously combined, and the film also achieved success at the box office.

In recent years, the growth in the size of film audiences has led to a more mature film consumption market. In 2018, the literary adaptation film Forever Young finally gained 750 million yuan at the box office with a culturally profound theme and a strong cast, which made the film the best film adapted from a novel in 2018. Another good literary adaption is Long Day's Journey into Night, with a cast of film celebrities, such as Tang Wei, Huang Jue, and Zhang Aijia, and it received positive reviews, and it also achieved good box office. There are also a number of art house films, such as Baby, Last Letter, Ash Is Purest White, which have won awards at international film festivals and received positive film reviews. At the same time, the number of documentaries has also increased. The documentary film, Amazing China, has an inspiring theme, attracting audiences from all ages and backgrounds, and finally achieved a box office total of 480 million yuan.

Compared with 2015 and 2016, the production of fantasy genre films has declined for two consecutive years. Monster Hunt 2 (2018) was an exception because it was released during the Chinese Spring Festival holiday season and audience are fans of this series. It gained the first place with 2.2 billion yuan at the box office, but the market response to other fantasy films was not so positive. The big budget fantasy film The Monkey King 3 only took a box office of 730 million yuan during the Spring Festival holiday season. Face of My Gene (169.8 million yuan), Airpocalypse (123.59 million yuan), Cinderella and the Secret Prince (60.14 million yuan), Ashura (49.84 million yuan), God of War (3,808,000 yuan), The Frozen Hero II (34.49 million yuan), Gu Jian Qi Tan II (14.12 million yuan), When Robbers Meet the Monster (7.95 million yuan) and other fantasy movies all had a poor reception. Fantasy movies have innate advantages over other genres in terms of special effects, but the highquality content of a film's story is the first motivation for moviegoers to enter a cinema. 
Table 9.3 Top 10 in the box office list of China's animation film market in 2018 (¥100 million)

\begin{tabular}{rlll}
\hline Rank & Movie title & $\begin{array}{l}\text { Total box } \\
\text { office }\end{array}$ & $\begin{array}{l}\text { Country of } \\
\text { origin }\end{array}$ \\
\hline 1 & Bear Emergence & 6.055 & China \\
2 & The Incredibles 2 & 3.544 & USA \\
3 & Spider-Man: Into the Spider-Verse & 3.542 & USA \\
4 & Ralph Breaks the Internet & 2.711 & USA \\
5 & Hotel Transylvania 3: Summer Vacation & 2.229 & USA \\
6 & Doraemon: Nobita's Treasure Island & 2.093 & Japan \\
7 & Ferdinand & 1.720 & USA \\
8 & Peter Rabbit & 1.684 & USA \\
9 & Totoro & 1.595 & Japan \\
10 & The Big Head Son and Little Head Father 3 & 1.582 & China \\
\hline
\end{tabular}

Source: Entgroup Data.

The imported animation films released in 2018 are still highly popular due to their strong special effects and sophisticated production quality. The 63 animation films released throughout 2018 include 32 domestic animation films, 29 imported animation films, and 2 co-produced films. Although the number of domestic animation films is higher than that of imported animation films, the latter still achieved much better results at box office because of their production quality and special effects. Eight of the top ten at the animation movie box office were imported films (Table 9.3).

The two domestic animation films on the list occupied the top and bottom positions, and Bear Emergence was the box office champion of animation films in 2018, with a box office total of 65.55 million yuan. It is not difficult to trace the market performance of animation films over the years. The advantages of a series of animation films are obvious. The two domestic animation films on the list in 2018 are both film series, and most of the imported animation films on the list are also film series. The success of animation films is ultimately due to the success of special effects development, so Chinese animation films need to catch up with imported animation movies, not only in terms of technology, but also in special effects development and promotion.

In recent years, many outstanding films directed by newcomers have emerged. The works of young directors contributed more than 10 billion yuan to the box office in 2018, and some of them are debut productions. Young directors became the backbone of the film industry and gradually became the mainstream filmmakers for domestic films in 2018. For example, Wen Muye's Dying to Survive, Rao Xiaozhi's A Cool Fish, Han Yan's Animal World, Huang Bo's The Island, Xin Yukun's Wrath of Silence, and Peng Fei's The Taste of Rice Flower have injected fresh blood into the film industry, with new filmic language and a more distinctive personal style. 


\section{A comparative analysis of domestic films and imported movies in 2018}

The year 2018 saw a rise in the numbers of domestic films produced. Although 124 foreign language films were released that year, the numbers of domestic films were outstanding: 19 domestic films gained at the box office more than 500 million yuan, and 8 domestic films exceeded 1 billion yuan box office, with a total box office score of 36.6 billion yuan. The market share was 60 percent which is an increase of 21 percent compared to that of the same period of the previous year. It is worth mentioning that the top 3 at the box office were also domestic films, namely, Operation Red Sea (36.5 billion yuan), Detective Chinatown 2 (3.4 billion yuan) and Dying to Survive (3.1 billion yuan). In competing with imported blockbusters, domestic films took first place in both box office performance and audience popularity. With local narratives and realistic themes that reflect the daily lives of Chinese people, these films were already in a better position to compete with imported films. The Open Door policies for the Chinese film industry, the increasing emergence of young film talents, the improvement of the film management system, and benign competition within the industry, all these created an environment in which only films of good quality will be successful. At the same time, the domestic audience's appreciation of good quality domestic films has increased, leading to a high market demand for domestic film production. But, of course, the competition from imported films still remained. In 2018, the number of imported films increased, and the performance of the US domestic market was weak. In order to inspire the audiences, the film Aquaman was released in China two weeks ahead of its release in North America, which proves that the Chinese film market is important to Hollywood. The imported films' total box office in 2018 was 24.1 billion yuan, accounting for 40 percent of the total box office.

Comparing the imported and domestic production of the top 20 Chinese box office in 2017 and 2018, among the top 20 in 2017, there were 8 domestic films and 12 imported films. In 2018, there were 12 domestic films and 8 imported movies (Table 9.4). Compared to the box office champion of 2017, Wolf Warriors 2, the overall competitiveness of domestic films in 2018 has been significantly enhanced, and they are the top four in the box office. The top three have all achieved excellent performances of over 3 billion yuan at the box office.

For both domestic movies and imported movies, high-quality content has become a driving force for films to gain economic and popular success. Domestic films are strong in comedy and drama, but in science fiction, animation and other genres, they are still relatively weak. With the competition within the industry and the opening up of the Chinese film market, the future of China's film production industry is ready to embark on a healthy path with improved product content and optimization of film resource allocation. The competitiveness of domestic films will continue to increase. The year 2018 
Table 9.4 Top 20 Chinese box offices, 2017-2018 ( 100 million)

\begin{tabular}{|c|c|c|c|c|}
\hline \multirow[t]{2}{*}{ Rank } & \multicolumn{2}{|l|}{2017} & \multicolumn{2}{|l|}{2018} \\
\hline & Movie title & $\begin{array}{l}\text { Box } \\
\text { office }\end{array}$ & Movie title & $\begin{array}{l}\text { Box } \\
\text { office }\end{array}$ \\
\hline 1 & Wolf Warriors 2 & 56.79 & Operation Red Sea & 36.51 \\
\hline 2 & The Fate of the Furious & 26.71 & Detective Chinatown 2 & 33.98 \\
\hline 3 & Never Say Die & 22.02 & Dying to Survive & 31.00 \\
\hline 4 & Kung Fu Yoga & 17.53 & Hello Mr. Billionaire & 25.48 \\
\hline 5 & $\begin{array}{c}\text { Journey to the West: The } \\
\text { Demons Strike Back }\end{array}$ & 16.56 & Avengers: Infinity War & 23.91 \\
\hline 6 & $\begin{array}{l}\text { The Ex-file: The Return of } \\
\text { The Exes }\end{array}$ & 16.47 & Monster Hunt 2 & 22.37 \\
\hline 7 & $\begin{array}{l}\text { Transformers: The Last } \\
\quad \text { Knight }\end{array}$ & 15.51 & Venom & 18.70 \\
\hline 8 & Dangal & 12.99 & Aquaman & 18.52 \\
\hline 9 & Youth & 11.88 & $\begin{array}{l}\text { Jurassic World: Fallen } \\
\text { Kingdom }\end{array}$ & 16.96 \\
\hline 10 & $\begin{array}{l}\text { Pirates of the } \\
\text { Caribbean: Dead Men Tell } \\
\text { No Tales/Salazar's Revenge }\end{array}$ & 11.80 & Ready Player One & 13.97 \\
\hline 11 & Kong: Skull Island & 11.60 & Us and Them & 13.62 \\
\hline 12 & Coco & 11.53 & The Island & 13.55 \\
\hline 13 & $x X x:$ Return of Xander Cage & 11.27 & Project Gutenberg & 12.74 \\
\hline 14 & $\begin{array}{l}\text { Resident Evil: The Final } \\
\text { Chapter }\end{array}$ & 11.12 & $\begin{array}{l}\text { Mission: Impossible - } \\
\text { Fallout }\end{array}$ & 12.45 \\
\hline 15 & Duckweed & 10.49 & The Meg & 10.52 \\
\hline 16 & Despicable Me 3 & 10.38 & Rampage & 10.04 \\
\hline 17 & Spider-Man: Homecoming & 7.74 & How Long Will I Love You? & 9.00 \\
\hline 18 & Buddies in India & 7.58 & Ant-Man and the Wasp & 8.32 \\
\hline 19 & Thor: Ragnarök & 7.43 & A Cool Fish & 7.94 \\
\hline 20 & War for the Planet of the Apes & 7.40 & Forever Young & 7.54 \\
\hline
\end{tabular}

Source: Entgroup Data.

was the strongest year for domestic movies in recent years, and they achieved better performance compared to imported films.

\section{Analysis of Chinese film production companies in 2018}

\section{Overview of the traditional Chinese state-owned and private film production companies in 2018}

On the one hand, state-owned film companies, such as the China Film Group Corporation, the Huaxia Film Distribution Corporation and the Shanghai Media Group actively responded to the call of the government, with the production of a number of films which successfully promoted the main ideology. On the other, they took advantage of resources and brand 
influence to actively participate in the investment of high-quality commercial blockbusters. In 2018, the China Film Group Corporation participated in the production and distribution of 22 domestic films, and its documentary film Amazing China achieved a box office of 480 million yuan. The number of domestic films that Huaxia produced was 111 films, including many films such as Project Gutenberg (1.27 billion yuan), Monster Hunt 2 (2,24 billion yuan), The Monkey King 3 (730 million yuan), and so on. The Shanghai Film Studio produced 9 films, such as Ipartment (555 million yuan), European Raiders (153 million yuan), Lost, Found (285 million yuan), Ash Is Purest White (69.974 million yuan), and the animation film The Adventures of Avanti (76.92 million yuan).

As shown in Table 9.5, of the top ten production companies for domestic film box office in 2018, there are several well-established private film companies such as Bona Film Group Limited, Wanda Media and Enlight Pictures. Detective Chinatown 2, mainly financed by Wanda, achieved second place at the annual box office. Operation Red Sea and Project Gutenberg, mainly financed by Bona, respectively won the annual box office champion and National Day Champion. The Island and How Long Will I Love You?, both financed by Enlight, also gained a higher box office. In 2018, Wanda, Enlight and Bona produced 16 films, 12 films and 9 films, respectively. These films made their production companies the top private companies in China in terms of film quality and quantity. Huayi's market competitiveness has been weakened because of the controversial issues with the new film project Phone 2. But the films such as The Ex-file, the art house film Ash Is Purest White, and the realist film Lost, Found, produced by Huayi, have all achieved good box office performance. In March 2018, LeTV Film was renamed LEVP Entertainment. It managed to maintain its market share by producing the new film Shadow, directed by Zhang Yimou. The above-mentioned well-established private film production companies have maintained their good positions in the Chinese film market for many years (Table 9.6).

\section{Overview of the films produced by the Chinese Internet and emerging film production companies in 2018}

In recent years, among a number of Internet film companies, Tencent and Ali have undoubtedly maintained their dominant duopoly position. Their ability to control product content has been increasing on a yearly basis, leading to a profound impact on the pattern of the Chinese film industry. Especially with the data and publicity platform support of MaoYan Entertainment and Tao Piaopiao, the two companies are developing strongly. In 2018, Ali Films produced Dying to Survive, Kill Mobile, and seven other films, which were all successful at the box office. Tencent Pictures and Penguin, which are both Tencent's companies, financed 13 movies in 2018. Tencent Pictures released Shadow, Boonie Bears, Animal World and eight other films. Penguin Film and Television released five films, including Forever Young and Monster Hunt 2. 
Table 9.5 Top 20 domestic film production companies at the box office in 2018

\begin{tabular}{|c|c|c|}
\hline Rank & Movie titles & Main production companies \\
\hline 1 & $\begin{array}{l}\text { Operation Red } \\
\text { Sea }\end{array}$ & $\begin{array}{l}\text { Bona Film Group, Chinese Academy of People's } \\
\text { Liberation Army Naval Political Department } \\
\text { Television Arts Centre, Online Star Dream Works, } \\
\text { Emperor Entertainment Group Limited }\end{array}$ \\
\hline 2 & $\begin{array}{l}\text { Detective } \\
\quad \text { Chinatown } 2\end{array}$ & $\begin{array}{l}\text { Wanda Media Co. Ltd, Shang Hai Shine Asia Movie \& } \\
\text { Culture Media Co., Ltd }\end{array}$ \\
\hline 3 & Dying to Survive & $\begin{array}{l}\text { Hua Manshan Group Limited, Joy Leader, Huanxi } \\
\text { Media Group Limited, Beijing Culture, Qiankun } \\
\text { Xingyu Group Limited, } \\
\text { Tang De Limited, Dirty Monkeys Studio }\end{array}$ \\
\hline 4 & $\begin{array}{l}\text { Hello Mr. } \\
\quad \text { Billionaire }\end{array}$ & $\begin{array}{l}\text { Xingkong Shengdian Group Limited, Xi Hongshi } \\
\text { Group Limited, Mahua Fun Age, New Classics } \\
\text { Media, Alibaba Pictures Group Limited }\end{array}$ \\
\hline 5 & Monster Hunt 2 & $\begin{array}{l}\text { Ying Du Media, Lanse Xingkong Group Limited, } \\
\text { Chinese Film, Anle, Shanghai Tencent Penguin Film } \\
\text { Culture Communication Co., Ltd, Huaxia Film } \\
\text { Distribution Co. Ltd., Zhe Jiang Film and Television }\end{array}$ \\
\hline 6 & Us and Them & $\begin{array}{l}\text { Shi Gu Film Company, Ying Er Film Company, } \\
\text { MaoYan, Huahua Duoduo Company }\end{array}$ \\
\hline 7 & The Island & $\begin{array}{l}\text { Han Na Film and Television Company, Enlight Media, } \\
\text { Spring Fusion Media Co., Ltd., Youth Light Film, } \\
\text { Le Flower Film }\end{array}$ \\
\hline 8 & Project Gutenberg & $\begin{array}{l}\text { Bona Film Group, Emperor Entertainment Group } \\
\text { Limited, Alibaba Pictures Group Limited }\end{array}$ \\
\hline 9 & The Meg & $\begin{array}{l}\text { Chinese Culture Group Corporation, Gravitational } \\
\text { Film and Television Investment Co., Ltd., Warner } \\
\text { Bros. Pictures }\end{array}$ \\
\hline 10 & $\begin{array}{l}\text { How Long Will } \\
\text { I Love You? }\end{array}$ & $\begin{array}{l}\text { True Music Culture, Youth Light Film, Jing Wumen } \\
\text { Culture Company, Eight Media }\end{array}$ \\
\hline
\end{tabular}

Source: Entgroup Data.

Baidu's iQiyi production company released A or B, I Am Your Mom and six other films. A Cool Fish was the product of several companies mentioned above which jointly produced this film. In the era of digital technology, Internet companies have obvious strength in the Chinese film industry, and their industry competitiveness is increasing year by year.

In recent years, many new, previously unknown film company names have emerged in the Chinese film industry, and some of them are production companies for the top ten films at the 2018 national box office. Most of these companies are led by established filmmakers or actors. These filmmakers contributed to content selection and film production based on their rich filmmaking experience and superior resources in the industry. Ning Hao's Dirty Monkeys Studio and Xu Zheng's Joy Leader jointly produced Dying to Survive. In addition, Joy Leader also produced The Wind Guardians, A or B, How Long Will I Love You? and many other films. Chen Guofu's Gongfu Film 
Table 9.6 Overview of film production by Chinese major film production companies in 2018

\begin{tabular}{|c|c|c|}
\hline Company & Number & Movie titles \\
\hline Zhong Ying & 22 & $\begin{array}{l}\text { Detective Chinatown 2, Monster Hunt 2, Forever Young, } \\
\text { The Monkey King 3, Amazing China, etc. }\end{array}$ \\
\hline Shang Ying & 9 & $\begin{array}{l}\text { iPartment, Lost, Found, European Raiders, The } \\
\text { Adventure of Afanti, } \\
\text { Ash Is Purest White, etc. }\end{array}$ \\
\hline Wanda & 16 & $\begin{array}{l}\text { Detective Chinatown 2, Dying to Survive, Detective Dee, } \\
\text { Bear Emergence, Hello Mrs. Money, etc. }\end{array}$ \\
\hline Bona & 9 & $\begin{array}{l}\text { Operation Red Sea, Project Gutenberg, Shadow, Big } \\
\text { Brother, Happiness Comes Right Away, etc. }\end{array}$ \\
\hline Huayi & 6 & $\begin{array}{l}\text { Detective Dee, Lost, Found, Fat Buddies, Yunnan Valley, } \\
\text { Ash Is Purest White, Nice to Meet You, etc. }\end{array}$ \\
\hline Enlight & 12 & $\begin{array}{l}\text { Detective Chinatown 2, A Cool Fish, How Long Will } \\
\text { I Love You?, Bear Emergence, Animal World, etc. }\end{array}$ \\
\hline LEVP & 3 & Shadow, The Frozen Hero 2, etc. \\
\hline Beijing Culture & 7 & $\begin{array}{l}\text { Dying to Survive, A Cool Fish, Kill Mobile, A Better } \\
\text { Tomorrow 2018, BABY, Cats and Peachtopia, etc. }\end{array}$ \\
\hline Yaolai & 8 & $\begin{array}{l}\text { Detective Chinatown 2, The Monkey King 3, The Island, } \\
\text { Lost, Found, A Cool Fish, Kill Mobile, etc. }\end{array}$ \\
\hline Ali & 7 & $\begin{array}{l}\text { Operation Red Sea, Dying to Survive, Hello Mr. } \\
\text { Billionaire, The Island, Project Gutenberg, etc. }\end{array}$ \\
\hline Tencent & 8 & $\begin{array}{l}\text { iPartment, Bear Emergence, Shadow, Animal World, } \\
\text { A Cool Fish, etc. }\end{array}$ \\
\hline Penguin & 5 & $\begin{array}{l}\text { Forever Young, Monster Hunt 2, Yunnan Valley, End of } \\
\text { Summer, Fate Express etc. }\end{array}$ \\
\hline IQIYI & 6 & $\begin{array}{l}\text { A Cool Fish, A or B, I Am Your Mom, Really? The } \\
\text { Blizzard, etc. }\end{array}$ \\
\hline
\end{tabular}

Source: Entgroup Data.

Production was the main producer of the film Detective Dee. Hidden Man, Einstein and Einstein, and Wrath of Silence were produced by Cao Baoping, Xin Yukun and other famous directors in cooperation with HeHe Film. Yan Fei and Peng Damo's Xi Hongshi Film Corporation produced the movie Hello Mr. Billionaire. And A Cool Fish was produced by Rao Xiaozhi's Shaonian Pie Film (Table 9.7). The cutting-edge independent filmmaking companies, with filmmakers as their core, have an innate advantage in the production of film content. In future, this sector is bound to compete with traditional major film companies.

Nowadays, Internet film companies, traditional major film production companies, distribution companies and cutting-edge film production companies often join together to produce film projects. This helps them avoid the high cost of film production and low output risk, and they benefit from each other's resources. This has become the basic model of film production. In the top ten domestic films in the box office rankings of 2018, the average number of companies participating in a film project exceeded 20. Among them, there 
Table 9.7 Overview of the films produced by Chinese film companies in 2018 (¥ 100 million)

\begin{tabular}{|c|c|c|c|}
\hline Company & Movie titles & Number & $\begin{array}{l}\text { Total box } \\
\text { office }\end{array}$ \\
\hline Huanxi & $\begin{array}{l}\text { Us and Them, Dying to Survive, Ash Is } \\
\text { Purest White, Nice to Meet You }\end{array}$ & 4 & 45.82 \\
\hline $\mathrm{HeHe}$ & $\begin{array}{l}\text { Hidden Man, Einstein and Einstein, Wrath } \\
\text { of Silence, Till the End of the World }\end{array}$ & 4 & 9.23 \\
\hline Shaonian Pai & A Cool Fish, etc. & 4 & 8.39 \\
\hline XiaoMi & $\begin{array}{l}\text { Detective Chinatown 2, Hello } M r . \\
\text { Billionaire, } A \text { or } B \text {, Girlfriend } 2\end{array}$ & 4 & 63.66 \\
\hline Joy Leader & $\begin{array}{l}\text { Dying to Survive, How Long Will I Love } \\
\text { You?, A or B, The Wind Guardians }\end{array}$ & 4 & 44.71 \\
\hline XinLi & $\begin{array}{l}\text { Kill Mobile, Hello Mrs. Money, Hello } \\
\quad \text { Mr. Billionaire }\end{array}$ & 3 & 36.79 \\
\hline $\mathrm{HanNa}$ & $\begin{array}{l}\text { The Island, A Strong Insect Crossing the } \\
\text { River, The Monkey King } 3\end{array}$ & 3 & 23.74 \\
\hline MaHua & Hello Mrs. Money, Hello Mr. Billionaire & 2 & 31.52 \\
\hline RuYi & Animal World, Airpocalypse & 2 & 6.32 \\
\hline GongFu & Detective Dee & 1 & 6.06 \\
\hline Dirty Monkeys & Dying to Survive & 1 & 31.00 \\
\hline Xi Hongshi & Hello Mr. Billionaire & 1 & 25.48 \\
\hline
\end{tabular}

are 46 in The Monkey King 3, 38 in Operation Red Sea, and 36 in The Island. And even for low and medium budget movies like A Cool Fish and Forever Young, there are 23 and 16 companies involved, respectively. Co-production has become the best way for current movie products to succeed in the Chinese film industry.

\section{Conclusion}

The year 2018 was when the internal and external environment of the Chinese film industry underwent major changes. The film industry in China increasingly experienced supervision and governance by the national administrative departments. The industrial capital market suffered difficulties, and fiscal and taxation policies suddenly were changed. There were worries about the prospects of the Chinese film industry in 2018, but the outstanding achievements of Chinese films at the end of the year prove that "every cloud has a silver lining." The domestic film production reached a peak in recent years in terms of both the number of films produced and the cinematic quality. The production chain is the most important part of the film industry chain. Traditional state-owned film production companies, private film production companies, and newly established film companies complement each other in terms of sharing resources. With increasing co-productions among them, more good quality films are being made for the audiences in China. 


\section{Bibliography}

China Statistical Yearbook (n.d.). Available at: www.chinayearbooks.com.

Hong Y., Tianyu L., and Yanbin S. (2019). Chinese Film Industry Memo in 2018, Movie Art, No. 2, 33-45.

Xiang G. (2018). Types of Film Integration, China Art News, November 14, 2018 , 3rd edn. 